\title{
Flash Flood Hazard Prediction of Shalatin City, Red Sea Coast, Egypt Utilizing HEC-RAS Model
}

\author{
Mona Sayed Hussein \\ Geography Department, Faculty of Arts, Cairo University, Giza, Egypt
}

\begin{abstract}
In terms of flood hazards, Shalatin is the least studied of the six major coastal cities in Egypt's Red Sea Governorate. The current study intends to determine the extent to which Shalatin city is exposed to flood hazard in an attempt to address this research gap. Urban flood modeling proved to be the most effective method. All the layers required for modeling were created in ArcGIS software at the greatest possible resolution using remote sensing products and data obtained during the field investigation. Three potential flood events were modeled as one-dimensional unsteady flow using the most recent version (6.0) of the HECRAS programme. To quantify the extent of flooding and water depth, as well as the water velocity and flood hazard, three types of maps were created. In comparison to other cities along Egypt's Red Sea coast, the data reveal that Shalatin appears to be less prone to floods. To safeguard the most susceptible areas, two earthen dykes, each around 2000 metres long, are recommended. The current study is the first to tackle the simulation of an Egyptian city's urban flood at a resolution of up to a single building.

Keywords: Flash flood, HEC-RAS, Modeling, Prediction, Urban floods.
\end{abstract}

\section{INTRODUCTION}

Flooding can have serious impacts on peoples and economy. The immediate impacts may include loss of human life, damage to infrastructure, destruction of or damage to property, and damage to build and natural environments. In the longer term, floods can also cause health problems and financial hardship which last for many years (Lamond et al., 2012). The most notable of the long-lasting impacts are the trauma symptoms caused by the death of the loved ones. In the last decades, the impacts of floods have increased worldwide as unusual weather conditions emerging from climate change are altering the rainfall patterns (Rajkhowa \& Sarma 2021). Equally important, though receiving less attention, is that population growth, rapid urbanization, and economic development in floodprone areas are exacerbating the hazards related to flooding (Hemmati et al., 2020).

Nowadays, flood mapping becomes an integral part of flood management (WMO \& GWP 2013). In some countries, the mapping activities are specified by legislations, e. g. the European Union Flood Directives (into force since 2007) requires that all member nations should assess all water courses and coastlines that are at risk from flooding, and draw up flood risk maps showing flood extent as well as assets and individuals at risk in these areas (https://ec.europa.eu/environment/water/flood_risk/, accessed 10 August 2021).

Developing flood hazard and flood risk maps often involves flood inundation modeling (Ali 2018). A model is a simplified representation of the real world using equations or a logical set of operations. The methodologies and techniques used for modeling flood hazards have been developed through more than hundred years of refining and testing. The early formulas, first devised about 1914, were simple statistical ones. Later on, it had been recognized that when statistical analysis is applied to the flood records at a single point, a large sampling error is involved. Thus a new concept evolves whereby data from a wide area are combined to establish generalized relation- ships applicable anywhere within the area (Benson 1962). The early versions of flood models, particularly the unit hydrograph, were originated in the 1930s. These models were event-based, that produce output only for specific time periods (Wheater 2008). This early approach is still widely used to predict floods (Solomatine \& Wagener 2011). It was not until 1960s that the continuous simulation of rainfall runoff processes was made available, thanks to the developments in computing power. The notable example of this second generation of models (now referred to as the conceptual models) is the Stanford Watershed Model. Although continuous in time representation, these models were of the lumped category, in which the parameters are spatially averaged to a single value representing the entire catchment. Models of this type are still at the heart of many operational forecasting systems. The third generation (now termed physically based models) took advantage of the continual increase in computing power and the developments in the field of geographic information systems (GIS) in the 1970s and 1980s. These are distributed models in which the model parameters vary spatially. As the recent developments have resulted in more complex data intensive models, the low-complexity floodplain mapping techniques are now promising alternatives (Diehl et al., 2021).

Notwithstanding all these developments, almost all modeling tools have been developed for humid area applications, while arid and semi-arid areas have received little attention (Wheater 2008). Moreover, many well developed methods may have little relevance to developing countries due to the lack of data. Therefore, the availability of data and the context of the study area are important considerations when modeling flood hazards (Dewan 2013). To fill the present data gaps, developing countries can rely on crowdsourcing using low-cost sensors for obtaining observations of hydrometeorological variables. However, due to their relatively low reliability, crowdsourced observations have not been widely integrated into flood forecasting models. Instead, they 
have been used to validate model results against observations (Mazzoleni 2016).

As vast expanses on the globe, including deserts and polar regions, are still suffering from the lack of ground-based measurements of hydrometeorological variables, remote sensing (RS) becomes instrumental in providing flood modelers with essential inputs required in addressing this challenge (Mujumdar and Kumar 2013). Additionally, the fact that a lot of the RS products are freely available data indicates the potential that such technology can be extended to developing countries that have not previously been able to benefit from flood predictions (Di Baldassarre 2013).

The case of the deserts of Egypt is an example of the complete lack of runoff data. It is striking to note that, apart from the River Nile proper, all other catchments that cover more than $500,000 \mathrm{~km}^{2}$ of the desert area are ungauged. These catchments were scenes of infrequent flash floods. For centuries, the floods went unnoticed as the area most prone to flooding remained sparsely populated. With the increase of population pressure in the Egyptian heartland, a tendency toward developing the periphery had begun since 1970s. As Hermas et al., (2021) point out, the low relief areas of the alluvial fans, wadi beds, and piedmonts represent the most favorable sites for urban development, albeit they are at the outlets of drainage basins.

The cities and infrastructures on the Red Sea coasts were scenes of the salient impacts of the recent destructive floods. A notable case is that of Wadi Abu Had in which the flood during October 2016 had resulted in tens of fatalities and widespread destruction to roads and homes in Ras Gharib city (Elnazer et al., 2017). Nowadays, the flood hazard to the Red Sea cities is recognized as the most significant natural hazard in terms of fatalities and economic damage

The flood hazards to five of the six main urban centers on the coast of Red Sea Governorate have been subjects of several studies; Ras Gharib (Yehia et al., 2000a; Elnazer et al., 2017 and Hermas et al., 2021), Hurghada and environs (Yehia et al., 2000a; Abd-Elhamid et al., 2018; Abdrabo et al., 2020 and Bauer et al., 2020), Safaga (Yehia et al., 2000b and Masoud 2004), Quseir (Yehia et al., 2000b; Mashaly \& Ghoneim 2018), Marsa Alam (Yehia et al., 2000b and Foody et al., 2004). To date, the flood hazard to Shalatin city is still a research gap (Fig. 1).

Another gap of research is that the published studies about the flood hazards to any Egyptian city are limited in scope to the hydrologic models. None of them contains a hydraulic model describing the flood behavior at any scale used in urban flood modeling. The only exception is the contribution made by Mashaly \& Ghoneim (2018) for the city of Quseir. However, its major limitation was that it depended exclusively on remotely sensed data without paying visit to the scene, and thus the maps depicting the results were too generalized to be described as urban floods model outputs.

The current study intends to address these two research gaps by answering two questions: To what extent

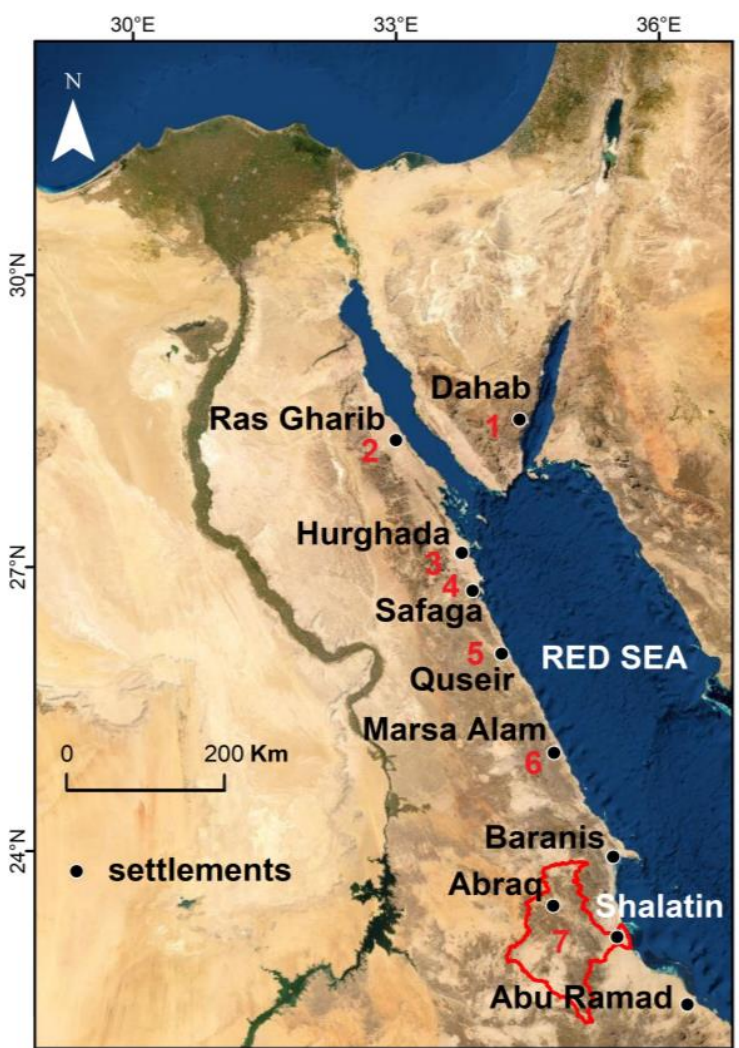

Figure (1): The Red Sea coasts of Egypt and their hinterland. Settlements are shown. The wadis (red number) are dry valleys: 1 , Wadi Dahab; 2, Wadi Abu Had; 3. Wadi Umm Sidr; 4, Wadi El Baroud; 5, Wadi El-Ambagi; 6, Wadi El-Alam; 7, Wadi Hudein (with a defined catchment area).

is Shalatin city vulnerable to flood hazard? And what mitigation strategies can be suggested? The easiest way to get the answers is to utilize a hydraulic model in a GIS context to identify the areas of Shalatin that are most vulnerable to flash floods and estimate the related hazard degrees. The current study is the first to use data from remote sensing and field studies to simulate urban floods with a resolution of up to single structures. It's also the first time an Egyptian city's urban flood has been simulated at this fine resolution.

\section{MATERIALS AND METHODS}

\section{Study area characteristics}

Located between $23^{\circ} 06^{\prime}$ and $23^{\circ} 09^{\prime}$ North and $35^{\circ} 33^{\prime}$ and $35^{\circ} 37^{\prime}$ East, Shalatin (variously transliterated as Shalateen or Al Shalateen) is the southernmost urban center on the Red Sea coast of Egypt, with almost 11,400 inhabitants according to the census of 2017, and an estimated population of 12,000 in 2021. Its built-up area is slightly less than $8 \mathrm{~km}^{2}$. The city is accessible through the main highway running alongside the coast, and is linked to Aswan in the Nile Valley through a paved road across the desert. In the aftermath of the socalled Third Halayeb Crisis in 1993, the Egyptian Government started a comprehensive plan to develop the long neglected south eastern part of Egypt. The plan envisaged, inter alia, the promotion of the then small settlement of Shalatin into a full-fledged urban center. Today, the economic base of the city is diversified, and depends on its administrative function, 
its unique camel market, as well as its role as service provider located on the main highway linking Egypt and Sudan. It also acts as service provider to the vast hinterland that extends as far as Abraq (westwards) and Abu Ramad (southwards) (personal communications in field study. So far, there are no studies available on the demography and economy of the city).

The location of the original settlement of Shalatin was chosen, by the local tribal groups, to be atop the fan of Wadi Hudein (variously transliterated as Hodein, Hudain or Hudin). Their intention was to reside as near as possible to Shalatin Wells, located in the midst of the course of the main channel that cuts through the fan. For centuries, these wells were a watering spot for camels and goats, thanks to the shallow water table created by infiltration of the waters of infrequent flash floods. These floods result from the draining of the vast (11,850 km²) Hudein Basin (Fig. 2).

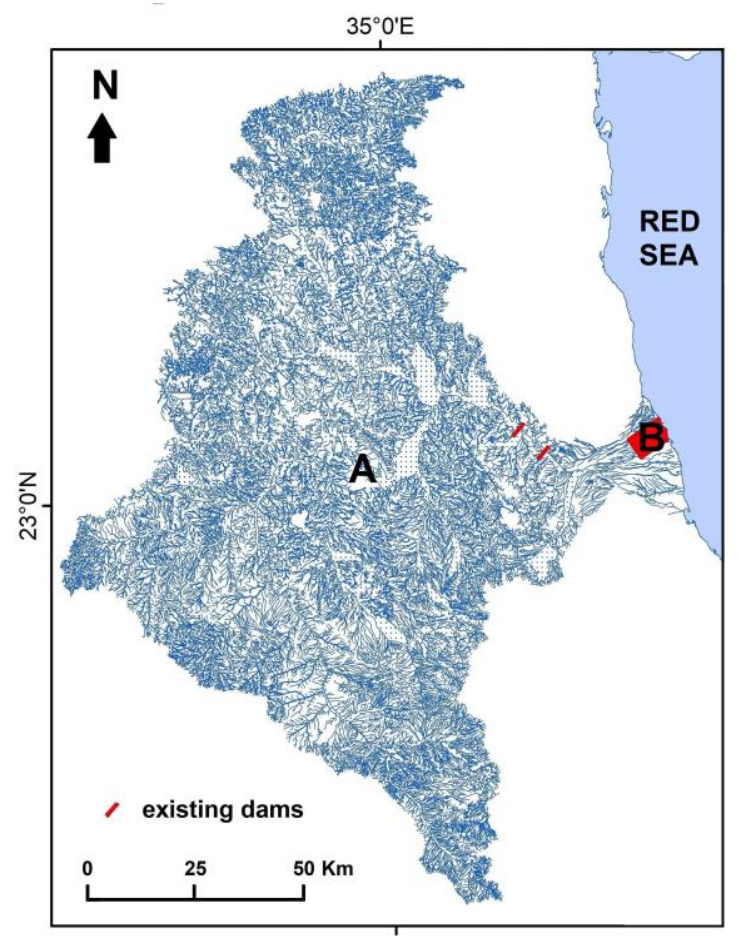

Figure (2): Location map of the study area, A, Wadi Hudein catchment; B, the study area.

The decision to locate the planned new quarters to be close to the main channel and the shore is taken by the government (Fig. 3). During the preparation of the city master plan, two alternatives were considered: planning a city with a maritime façade and tourism as the main economic base, and extending the then existing settlement. The final decision was to adopt the second alternative as it was found that the salt water, rising by capillarity, would severely damage the buildings and infrastructure (General Organization for Physical Planning 1995), and the plan called for "restricting the built up area between 10 and $30 \mathrm{~m}$ contour lines.

A characteristic synoptic feature of autumn in the study area is convective storms resulting from the northward incursion of the Active Red Sea Trough triggered by the upper level trough (De Vries et al., 2013 and Morsy et al., 2020). As most of the Hudein
Basin is covered by impervious basement rocks (Ghanem 1972, Shabana et al., 2003 and Sadek 2009), a considerable quantity of rainfall would create runoff. Additionally, the achievement of two "dams" on the main course of the wadi in 2019 puts the city at risk of flooding than ever before, if one of the dams suddenly fails.

\section{Studying the flooding event}

The urban flooding simulations are now the main tool that can give insights about flood hazards and risks (Eldho et al., 2018). To simulate an urban flooding event, two models may be constructed: 1 . hydrologic model that translates rainfall (at the catchment scale) into stormwater runoff after considering various losses, and, 2. hydraulic model that evaluates the transfer of stormwater flows through networks of infrastructure and across land surfaces. Typically, the input to the second model is the flow amount which is the output of the first model, and the main outputs of the second are the flow extent, the flow height, velocity, and degree of hazard. The simulations can be performed at different spatial scales, of which the smallest is that of a single small parcel of land with a single dwelling. At the other end of the spectrum of scale, the simulation may cover an entire suburb or even a small city (Coombes and Roso 2019). However, the representation of urban micro-features is critical to the accuracy of modeling results (Wang et al., 2018).

Flash floods occur as a result of the higher rate of precipitation than the infiltration rate, supported by increased land slopes. Another cause of flash flood is the collapse of dams and barriers (Fathy et al., 2020). Accordingly, the simulation of floods requires precipitation and/or overland flow data, topographic data, lithology and/or soil data, land use/land cover (LULC) map, the selection of a hydraulic model, geometric data as specified by the model.

\section{Hydrometeorological data}

The discharge hydrographs, for certain recurrence periods of 25, 50 and 100 years, can be constructed based on either flood data or rainfall data (Ball and Babister 2019). The efforts to quantify flash flood hazards in drylands are often hampered by the lack of data relevant to the overland flow. Faced by this stateof-affair, modelers usually use the morphometric parameters of the basin to estimate discharge hydrographs (Ghoneim et al., 2002, for Wadi El-Alam; Masoud 2004, for Wadi El Baroud and Omran et al., 2011, for Wadi Dahab). Additionally, Some researchers have devised novel approaches, of which the notables are: a, monitoring the increase in spectral reflectance (due to the deposition of fine sediments) of channels affected by a recent flash flood (El Bastawesy et al., 2009, for Wadi Hudein); and b, field measureements of recent flood debris (Abbas et al., 2020, for Wadi Umm Sidr).

The use of meteorological data to produce hydrographs is an alternative method that is likewise troublesome. Gheith and Sultan (2002) discovered that only four recording stations out of 13 in and around 
their study region were equipped and in working order to give valid hyetograph records in a study of the 1994 flooding episodes in the Eastern Desert. The available rainfall data for this study could not meet the minimum requirements because the Shalatin meteorological station was only established on January 1, 2001, and the nearest two meteorological stations (located in Baranis Air Force Base and Qusseir, respectively) are
95 and 350 kilometres away from Shalatin. Additionally, and most strikingly, there are no meteorological stations in the vast hilly country lying between the Red Sea coast and the Nile Valley. This fact led the compilers of the Climatic Atlas of Egypt (EMA 1996) to admit that "the situation in the Eastern Desert is rather difficult because there are no stations established over the chain of the Red Sea mountains".

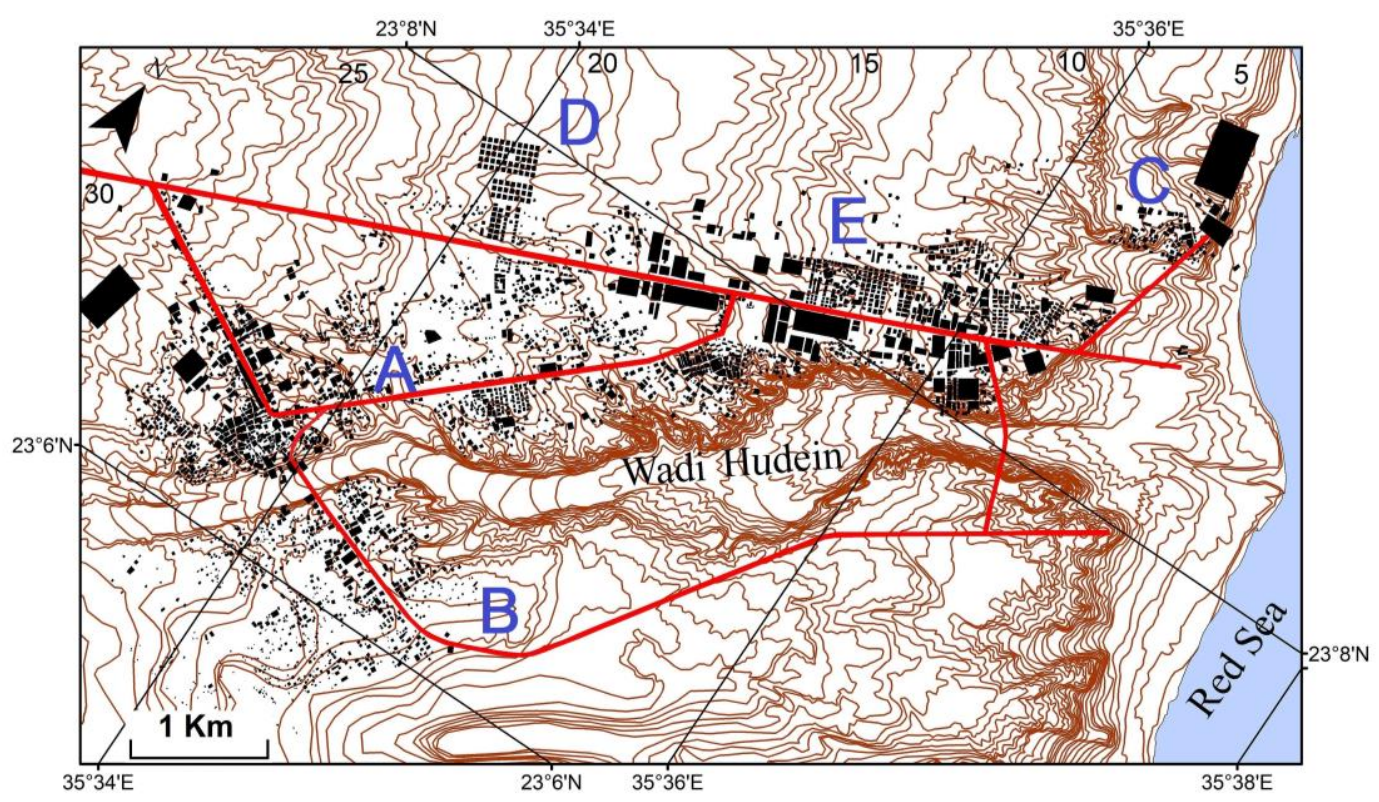

Figure (3): Shalatin's layout (December 2020) displays brown contours with a 0.5-meter interval; black built-up areas; unplanned settlements $(\mathrm{A}, \mathrm{B}$, and $\mathrm{C})$ are in the southwest and near the shore $(\mathrm{C}$, fishermen village); the planned model quarters are in the middle $(\mathrm{D}$ and $\mathrm{E})$.

The two long-time series of rainfall available for Qusseir (1927 onwards) and Baranis (1964 onwards) (Physical Department 1938, Meteorological Department 1950, Meteorological Authority 1979 and EMA 2011) give maximum rainfall in one day as high as 34 $\mathrm{mm}$ in Qusseir (recorded on 6 November 1934) and $48.0 \mathrm{~mm}$ and $68.2 \mathrm{~mm}$ in Baranis (recorded on 20 October 1979 and 6 May 1976 respectively). The effects of the future climate changes on precipitation cannot be anticipated, as the results obtained from various future climate models seem to be contradictory.

The remotely sensed precipitation data cannot be used to compensate for the lack in the rainfall data. In a comprehensive evaluation of the performance of the three globally high-resolution remotely sensed rainfall products for the Middle East, it was found that all products perform poorly in reproducing the anomalous wet events (El Kenawy et al., 2019). Suffice here is to show the cumulative rainfall in Wadi Hudein basin for the ten days (1 to 10 Nov. 2020) that witnessed $11 \mathrm{~mm}$ of rainfall in Shalatin station (as reported by the Egyptian Meteorological Authority). Figure 4 was constructed by converting precipitation data from a netCDF file into a raster dataset with one tenth degree of geographic resolution, then classifying the raster using ArcGIS 10.3 software.

The data are from the Global Precipitation Measurement Mission's (GPM) Final Run version of the product GPM 3IMER-GDF v06, and are publicly available at the National Aeronautics and Space Administration's (NASA) site:

"https://giovanni.gsfc.nasa.gov/giovanni/".

A consequence of the lack of the adequate meteorological data for the Eastern Desert is the lack of statistical studies addressing the extreme rainfall events for up to 100 years recurrence periods. Indeed, the study of Gado (2020) was the first in this respect, though it is limited southwards to Qusseir. Faced by the lack of data, the present study considered the results of studies of the comparable case of Wadi ElAlam (peak discharge $1,130 \mathrm{~m}^{3} / \mathrm{s}$, Ghoneim et al., 2002), and thus the hypothetical discharge hydrographs were assumed to be of a single peak, with peak discharge rates of $500,1,000$ and $1,500 \mathrm{~m}^{3} / \mathrm{s}$. These are a rather conservative estimates (to represent 25-100 years recurrence periods) if compared to a peak discharge of $875 \mathrm{~m}^{3} / \mathrm{s}$ for Wadi El-Ambagi that drains a catchment area of only $1,540 \mathrm{~km}^{2}$ (Mashaly \& Ghoneim 2018).

The peak discharge of $18,300 \mathrm{~m}^{3} / \mathrm{s}$ estimated by Elewa et al., (2020) should be regarded as overestimation, and is not considered here. Adopting hypothetical values for peak discharge eliminates the need for a hydrological model, and all that needed is the hydraulic one, in which the hydrographs are located at a cross section of the wadi lying just on the outskirts of the city, i.e. at $9.6 \mathrm{~km}$ from the outlet of the wadi into the Red Sea. 


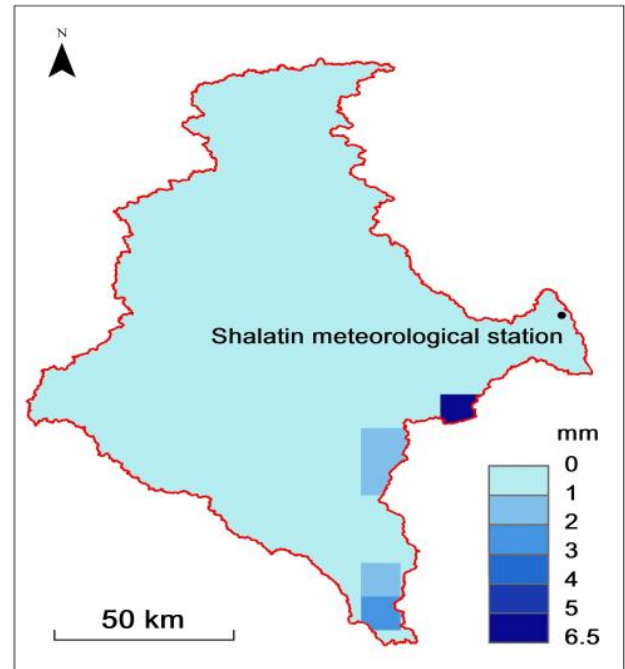

Figure (4): The cumulative rainfall in Wadi-Hudein basin, as acquired by GPM, for the ten rainy days of 1 to 10 November 2020. The dataset gives a remotely sensed value of less than 1 $\mathrm{mm}$ for the pixel containing Shalatin meteorological station, and under-estimates the observed value of $11 \mathrm{~mm}$.

\section{Topographic data}

Urban flood modeling requires a digital elevation model (DEM) of finer resolution than that of the freely available DEMs. The required resolution should capture the flood behavior at the street or the individual building level. Fortunately, the study area has recently been covered by contour map produced out of aerial photos (Military Survey Authority, 2003). The map is of $0.5 \mathrm{~m}$ contour interval. To convert the contours to a raster DEM (Fig. 5A) to be input later in the modeling software, the contours were first digitized as a shapefile layer in ArcGIS 10.3 software, and then interpolated using the Topo to Raster tool. The output DEM cell size was set as $2 \mathrm{~m}$.

\section{The LULC map}

The use of such a map is required for the assessment of environmental impacts (Arnous et al., 2017). In urban modeling the need of LULC is of threefold: (1) to convert the DEM to digital surface model (DSM), i.e. to add the footprints of buildings (Wang et al., 2018); (2) to be used, along with the soil texture map, to assign the Manning's n-values to each LULC category. The n-values express the roughness of the terrain and thus are parameters of any flood model; (3) to be used as a layer, among other layers of the results, in the visualization of the flood behavior, either as animation or still maps.

To produce a LULC map capable of satisfying these functions, a satellite image of ArcGIS World Imagery, up to one meter resolution, was used to create shapefiles in ArcGIS. The visual interpretation of these remotely sensed data (Fig. 5C) is based on a comprehensive survey of the urban features during field study of the city in 2018. Four main types of buildings can be recognized (Fig. 6). The sparsely distributed vegetation was extracted using imageries taken in October 2018 and verified in the field (Fig. 7). May, October and November are the months with high rainfall, and consequently flood probability, in southeastern Egypt (Table 1).

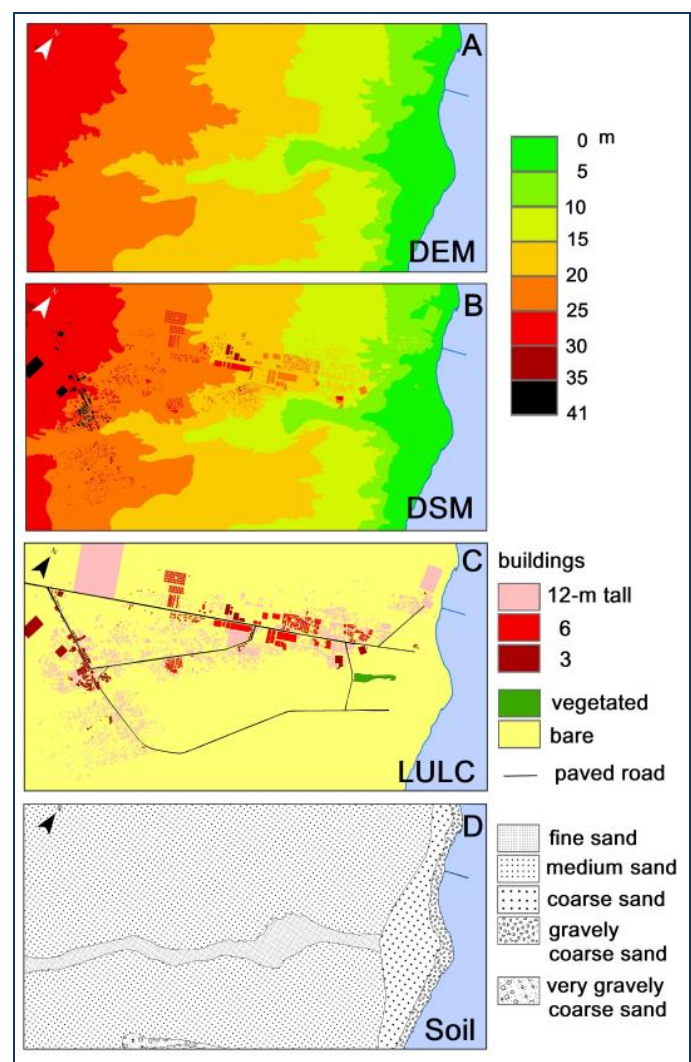

Figure (5): Four layers to be input in the model: A, DEM; B, DSM; C, LULC; D, soil texture

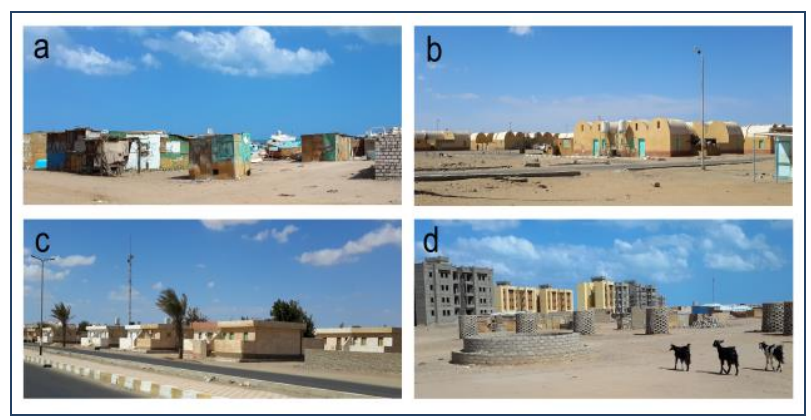

Figure (6): Examples of the four primary building types found in Shalatin. a) in unplanned quarters, fishermen's shanties; b) in planned quarters, bedouin sedentarization houses; c) in planned quarters, one floor; d) in planned quarters, four floors.

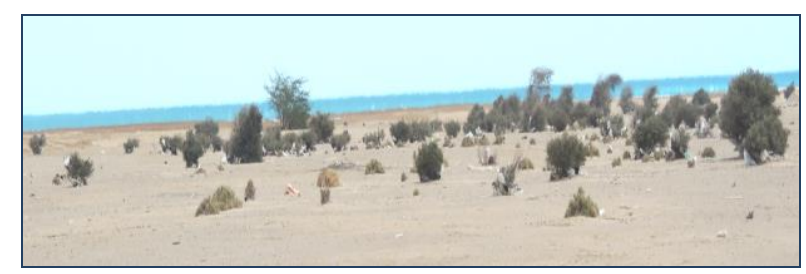

Figure (7): The vegetation in the Wadi Hudein bed, in the vicinity of the Shalatin Wells.

\section{The DSM}

The DSM (Fig. 5B) is created using the raster calculator tool in of ArcGIS software. The DSM is simply the algebraic sum of two layers; the DEM and the buildings footprints as classified in the LULC map.

\section{The Soil texture map}

This map is required by the model to assign Manning's value to each texture category. The map (Fig. 5d) was constructed based on the survey results of representative forty two soil profiles, reported in El- 
Taweel and Kotb (2006). The Manning's Roughness Coefficients (n) and the adjustment factors for irregularity (n1), variation in channel cross section (n2), obstructions (n3) and vegetation (n4), were taken from the guide adopted by the United States Geological Survey (Arcement \& Schneider, 1989).

\section{The selected model}

The latest version (6.0, launched in December 2020) of HEC-RAS software was used. This package was produced by Hydrologic Engineering Center of the US Army Corps of Engineers, and is freely available at Hydrologic Engineering Center's River Analysis System (HEC-RAS) website (https://www.hec.usace.army.mil/software/hec-ras/). HEC-RAS allows the user to perform, among other things, one-dimensional steady flow, and one and two-dimensional unsteady flow simulations (Brunner 2021).

Modeling the case study is better achieved using the one-dimensional unsteady flow option in HEC-RAS (for comparisons of the advantages, disadvantages and the computational details of $1 \mathrm{D}, 2 \mathrm{D}$ and $3 \mathrm{D}$ in HEC RAS, see Brunner et al., 2020). The 1D option assumes that the forces acting on a body of water are predominantly along the river channel centerline $(x-$ direction) and that the lateral forces (y-direction) and the vertical (z-direction) are negligible. The simulation results are displayed using the HEC-RAS Mapper module (Brunner 2020), which allows users to view inundation area, water depth, and water velocity as animated or static maps. In the Mapper module, users can also generate their own customized maps and animations. For instance, a flood hazard map can be created by multiplying the water depth layer by the water velocity layer using the raster calculator.

\section{The Geometric data}

Hydraulic models require the creation of "Geometry," of which only four are required in this study: "Centerline," which is the channel's centerline, "Banks," which are the channel's two banks, "Path," which is the flood plain's limit or the area prone to inundation, and "Cross Section," which are sections perpendicular to the channel and extending to the Path's limits. The geometries were digitized using the background layer ArcGIS World Imagery in the HECRAS Mapper module, and a total of ten cross sections were created, each around one kilometre apart (Fig. 8). Meanwhile, a flowchart summarizes the methods employed (Fig. 9).

\section{RESULTS AND DISCUSSION}

The model was run thrice to simulate three events of peak discharges of $500,1,000$ and $1,500 \mathrm{~m}^{3} / \mathrm{s}$. The results of the simulations are visualized in RAS Mapper as animations. Since the hypothetical discharge hydrographs are of 24 hours duration, and as the model was set so that the calculations are performed iteratively at 1 minute interval, a total of 1441 still maps can be obtained for any of the characteristics of the flood. To summarize, the study's goals are to

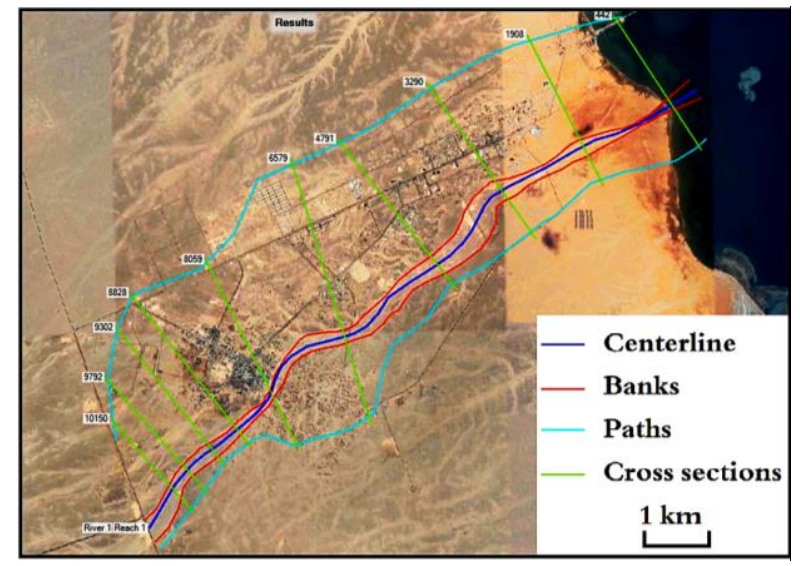

Figure (8): The geometric data required by the model.

visualize three maps: water depth, water velocity, and hazard (Depth X Velocity). The maps that illustrate the worst case scenario in terms of hazard maps were chosen for presentation here from among the numerous available. The worst scenario occurs 13 hours 15 minutes after the commencement of the flood in two events $\left(1,000\right.$ and $\left.1,500 \mathrm{~m}^{3} / \mathrm{s}\right)$, and 9 hours 10 minutes after the onset in the $500 \mathrm{~m}^{3} / \mathrm{s}$ instance. Figures (10), (11) and (12) illustrate the scenario at these points in time.

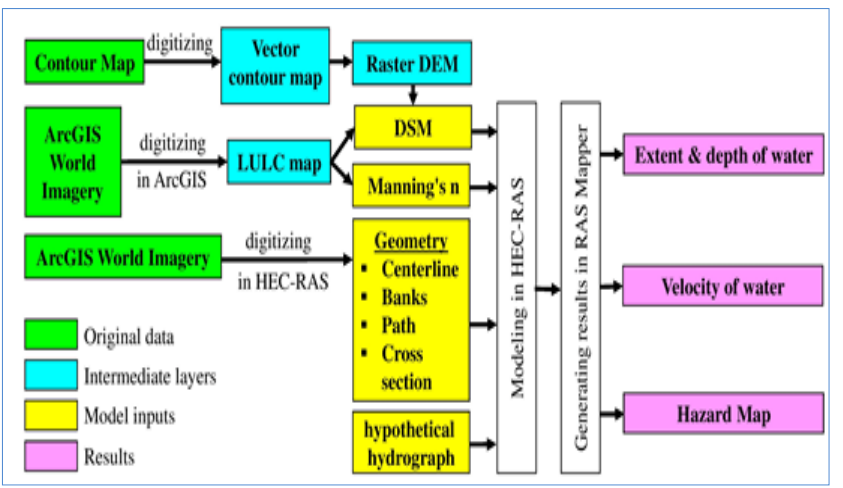

Figure (9): Flowchart of the methodology used.

The results show that, even with the conservative estimation of $500 \mathrm{~m}^{3} / \mathrm{s}$ peak discharge, a water depth as high as $1.5 \mathrm{~m}$ would build up at the most vulnerable areas, all of which belong to the unplanned quarters (officially categorized as squatted settlements). The city master plan (General Organization for Physical Planning 1995) calls for using the channel only as conduit for flood waters; however, the locals are repeatedly encroaching the channel, but they always face counter reactions taken by the authorities (Fig. 13).

The simulation results for the $1,000 \mathrm{~m}^{3} / \mathrm{s}$ peak discharge event show a higher water depth $(3 \mathrm{~m})$, localized mainly in the channel, and a depth of 1 to $1.5 \mathrm{~m}$ at the most vulnerable areas. The hazard of inundation, (Fig.11a), is further aggravated by the relatively high velocity of water (Fig. 11b), and this is why Fig. (11c) shows that tens of homes located near the channel are highly vulnerable. The results demonstrate no substantial divergence from the $1,000 \mathrm{~m}^{3} / \mathrm{s}$ simulation for the extreme situation of a $1,500 \mathrm{~m}^{3} / \mathrm{s}$ peak discharge, represented in Figure (12). 
Table (1): Average and maximum rainfall (mm) in one day for Baranis (Ras Banas) station (1976-2005, EMA, 2011).

\begin{tabular}{ccccccccccc}
\hline \hline \multirow{2}{*}{ Rainfall } & \multicolumn{10}{c}{ Month } \\
\cline { 2 - 9 } & Jan. & Feb. & Mar. & Apr. & May & Jun. to Sept & Oct. & Nov. & Dec. \\
\hline Average & 2.9 & 0.2 & 1.5 & 3.7 & 21.9 & 0 & 13.2 & 11.7 \\
Max & 5.5 & 0.2 & 2.8 & 12 & 68.2 & 0 & 48 & 20 & 0 \\
\hline \hline
\end{tabular}
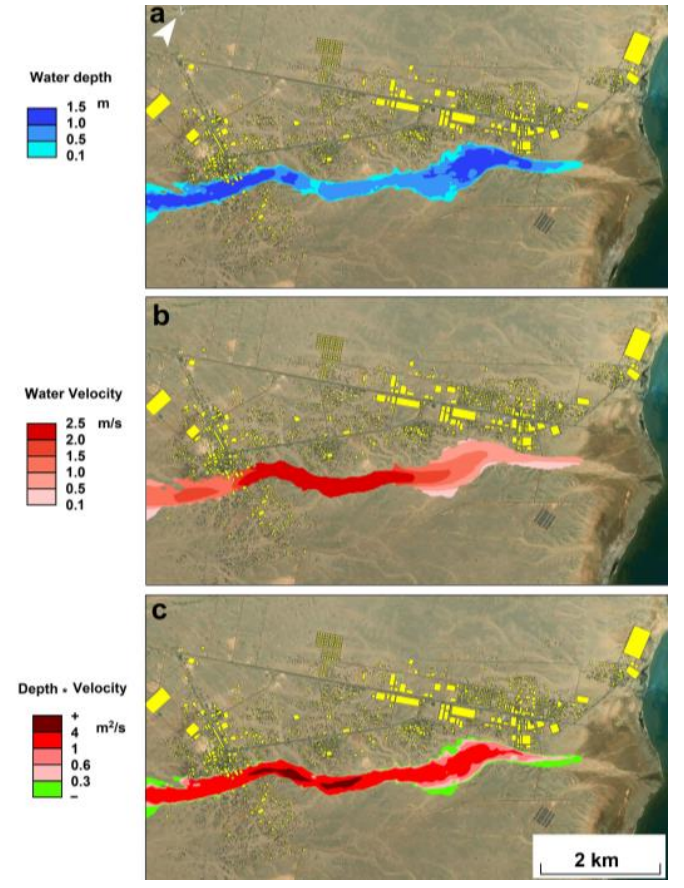

Figure (10): The outcomes of the worst case simulation of a 500 $\mathrm{m}^{3} / \mathrm{s}$ peak discharge event.

The fisherman villages, as well as certain public buildings in the planned quarters, are now at risk of flooding. In all scenarios, the most vulnerable areas are almost the same.

The building materials in these areas are predominantly wood, along with torn metal pieces and plastics. In some cases limestone is used, but without safety requirements. Such buildings cannot withstand heavy floods. Among the Red Sea coastal cities, Shalatin is unique in preserving this type of shanty houses. The only comparable case is that of the small settlement of Halayeb, located about $165 \mathrm{~km} \mathrm{SE}$ of Shalatin. Halayeb was given a city status in 2014 albeit being a mere shanty town of wood houses. Highly vulnerable to flooding, almost all Halayeb houses had been swept away or collapsed during the flooding disaster in November 2019.

The present model predictions fit well with the few known observations in comparable cases. In interviews with the Safagan people, Masoud (2004) reported $4 \mathrm{~m}$ water level in some parts of the city, and a $2 \mathrm{~m}$ water depth has been reported in Quseir during the 1994 and 1996 flash floods (Mashaly \& Ghoneim 2018). A similar depth of $2 \mathrm{~m}$ was reported in Ras Gharib in 2016 (El Nazer et al., 2017). However, due to the topography of Shalatin, the predicted water depth would be restricted in space, i. e. in the main channel and slightly beyond it. Thus, Shalatin seems to be less vulnerable to floods if compared to Ras Gharib which
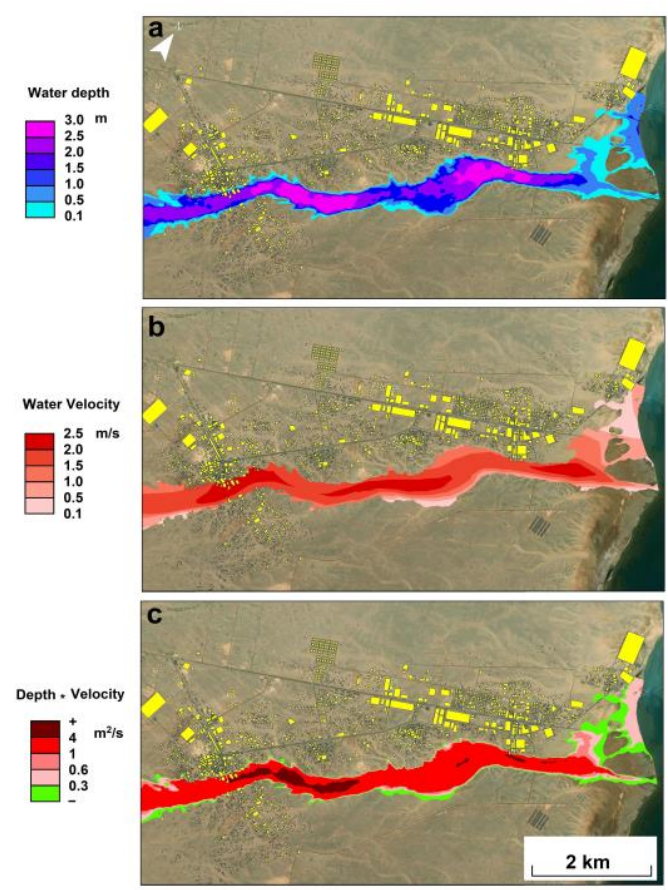

Figure (11): The outcomes of the worst case simulation of a 1,000 $\mathrm{m}^{3} / \mathrm{s}$ peak discharge event.

was almost totally inundated for six hours in the 2016 events. Also, the area prone to flooding in Shalatin is less than that predicted for Quseir according to the results of the model in Mashaly and Ghoneim (2018).

The interpretation of the three hazard maps (Figs. $10 \mathrm{C}, 11 \mathrm{C}$ and 12C) can be done using the Flood Hazard Vulnerability Curves, devised by Australia Water Research Laboratory (Smith et al., 2014), These curves (reproduced here as Fig. 14) have been measured in controlled tests and after extensive literature review. The five categories depicted in Figs. (11c), and (12c) correspond to the six categories depicted in Fig. 14, with $\mathrm{H}_{2}$ and $\mathrm{H}_{3}$ lumped together for convenience. The important result that can be deduced is that not only peoples and vehicles would be at high vulnerability, but even buildings would be vulnerable as well.

A limitation of the present study is that the calibration of the model cannot be achieved using remotely sensed data, as these data are not available for the very time of the known flood events. Calibration may not be possible even for further well-planned studies in the future, as the main channel upstream Shalatin had been dammed. This limitation of study is not specific to the Shalatin case. As Coombes and Roso (2019) put it as the opportunity for inundation model calibration for drylands is very limited and even is practically nonexistent. However, HEC-RAS predictions for different contexts have been proved to 

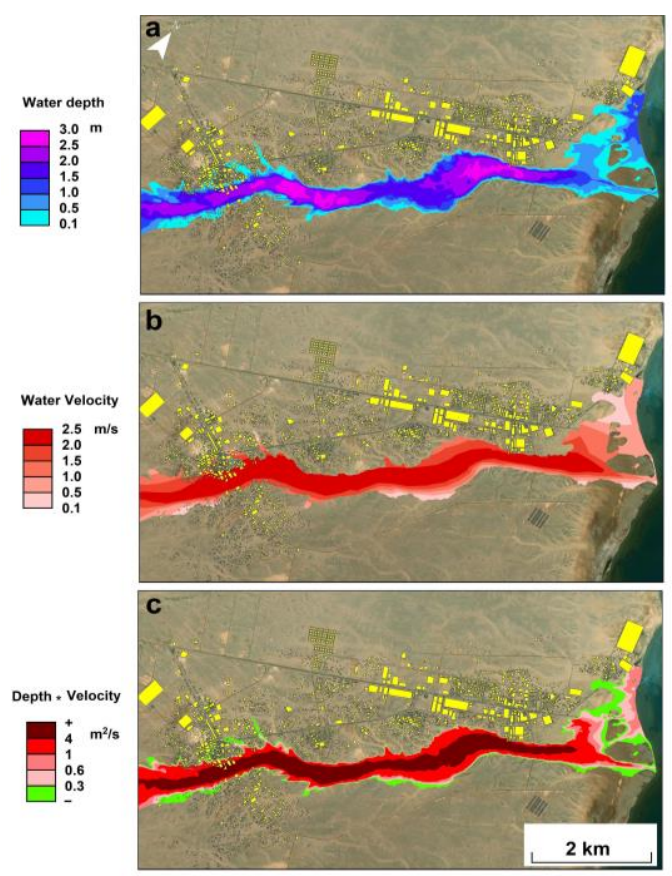

Figure (12): The outcomes of the worst case simulation of a 1,500 $\mathrm{m}^{3} / \mathrm{s}$ peak discharge event.

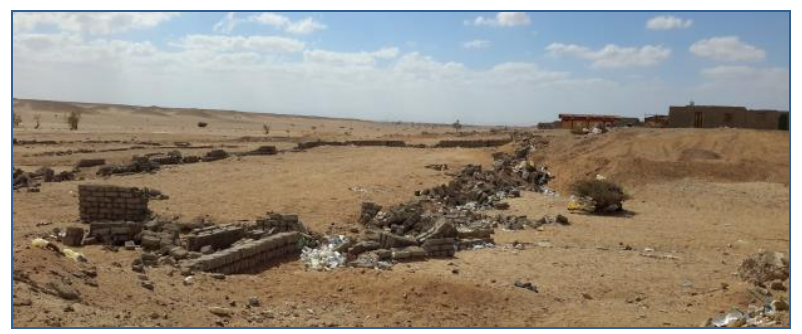

Figure (13): Illegal sprawls located in the bottom of Wadi Hudein channel, and demolished by the authorities.

fit welwith the observations. Today HEC-RAS model is one of the most commonly utilized flood modeling pieces of software in hydrodynamic simulation (Dasallas et al., 2019).

One of the implications for future research is that relying only on remotely sensed may prove to be a flawed approach. In a final report about the hazards of floods of Wadi Hudein (NARSS 1997) the investigators ranked the hazard as low. They ground their argumentation on theoretical bases, referring only to the topography of the watershed. In a later study on the wadi, El Bastawesy et al., (2009) concluded that runoff would be lost in transmission into the underlying alluvium before reaching the outlet at the coast. These views were challenged when, in November 2020, a year only following the damming of the main course, a long lake was formed as a consequence of a flood event. The two earthen dykes, achieved in 2019, dam the main course, giving rise to two retention basins, with total storage capacity of 16 million $\mathrm{m}^{3}$.

The work involved 5.4 million $\mathrm{m}^{3}$ of cut and 3.6 million $\mathrm{m}^{3}$ of fill. Paradoxically, the dykes that are intended to mitigate flash floods are themselves a new possible cause for more destructive floods, if one of them fails. Dam failure possibilities were never addressed in research though score of dams have been

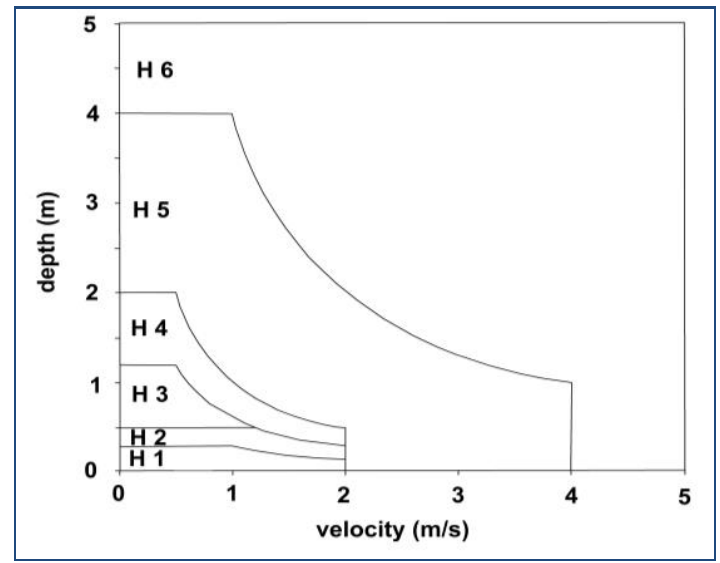

Figure (14): Flood Hazard Vulnerability Curves (after Smith et al., 2014). H1: safe for peoples, vehicles and buildings, H2: unsafe for small vehicles, H3: unsafe for vehicles, children and elderly, H4: unsafe for peoples and vehicles, H5: unsafe for peoples and vehicles, buildings require special design, H6: All building types are vulnerable to failure.

constructed on the main wadis in Egyptian deserts in the last two decades. To date, the only reported case of failure is that of Wadi Dahab dam in 2012 (AbdelFattah et al., 2015).

The construction of the two dykes would not guarantee the protection against possible severe flooding. Recommendations - in the light of the newly created situation include: (1) protecting the most vulnerable areas through the construction of two earthen dykes, each about $2000 \mathrm{~m}$ long, on both sides of the main channel. This may prove a temporary solution as the housing programs to eradicate the slums were shelved, (2) Initiating a research project to study all possible consequences of the failure of one of the dams, and the worst case of the successive failures of the two. The proposed project may be expanded to include other cases of Red Sea coastal cities.

\section{CONCLUSION}

In comparison to other settlements along the Egyptian Red Sea coast, Shalatin appears to be less vulnerable to floods, at least according to modeling data. Even with the lowest forecasts of peak discharge, however, some portions of the city could be flooded. The majority of the homes in these locations are made of wood and are therefore vulnerable. Because plans to rebuild the unplanned quarters beyond the vulnerable areas have been delayed, immediate mitigation measures should be performed, the most practical of which appears to be the wadi embankment within the built-up area. The city has not been effectively safeguarded by the construction of two dykes to dam the major channel. A heavy flood could force the dykes to fail. This evolving nature of flooding hazards puts the city in risk more than ever before, and future study should take this into account. The findings of this study are broadly applicable to various settlements along Egypt's Red Sea coast, as they share many commonalities in terms of local geography, land use/land cover, and the nature and severity of hazards. 


\section{REFERENCES}

ABBAS M., P.A. CARLING, J.D. JANSEN AND B.S. AL-SAQARAT. 2020. Flash-flood hydrology and aquifer-recharge in Wadi Umm Sidr, Eastern Desert, Egypt. Journal of Arid Environments 178: 104170.https://doi.org/10.1016/j.jaridenv.2020.104 170.

ABDEL-FATTAH M., S. KANTOUSH AND T. SUMI. 2015. Integrated management of flash flood in wadi system of Egypt: Disaster prevention and water harvesting. Annuals of Disaster Prevention Research Institute, Kyoto University, Japan 58 B: 485-469.

ABD-ELHAMID H.F., I. FATHY AND M. ZELEŇÁKOVÁ. 2018. Flood prediction and miti-gation in coastal tourism areas, a case study: Hurghada, Egypt. Natural Hazards 93: 559-576. https://doi.org/10.1007/s11069-018-3316-x

ABDRABO K.I., S.A. KANTOUSH, M. SABER, T. SUMI, O.M. HABIBA, D. ELLEITHY AND B. ELBOSHY. 2020. Integrated methodology for urban flood risk mapping at the microscale in ungauged regions: a case study of Hurghada, Egypt. Remote Sensing 12(21): 3548. https://doi.org/10.3390/rs12213548features.

ALI, A.B.M. 2018. Flood inundation modeling and hazard mapping under uncertainty in the Sungai Johor Basin, Malaysia. CRC Press, Boca Raton, Florida, USA.

https://doi.org/10.1201/9780429469015

ARCEMENT G.J. AND V.R. SCHNEIDER. 1989. Guide for Selecting Manning's Roughness Coefficients for Natural Channels and Flood Plains. United States Geological Survey Water Supply Paper 2339, Denver, USA. https://doi.org/10.3133/wsp2339

ARNOUS M.O., A.E. EL-RAYES AND A.M. HELMY. 2017. Land-use/land-cover change: a key to understanding land degradation and relating environmental impacts in Northwestern Sinai, Egypt. Environmental Earth Sciences 76: 263. https://doi.org/10.1007/s12665-017-6571-3

BALL J. AND M. BABISTER. 2019. A guide to flood estimation, Book 1: Scope and philosophy. The Australian Rainfall and Runoff, Barton, Australia.

BAUER F., A. HADIDI, F. TÜGEL AND R. HINKELMANN. 2020. Flash flood investigations in El Gouna, northern Red Sea Governorate. In A. Negm (Ed.), Flash Floods in Egypt 61-81. Springer, Cham, Switzerland. https://doi.org/10.1007/978-3030-29635-3-5

BENSON, M.A. 1962. Evolution of methods for evaluating the occurrence of floods, United States Geological Survey, Water Supply Paper 1580-A. https://doi.org/10.3133/wsp1580A

BRUNNER G.W. 2020. HEC-RAS Mapper, User's Manual, Version 6.0 December 2020. Hydrologic Engineering Center, Davis, California, USA.

BRUNNER G.W. 2021. HEC-RAS River Analysis System, User's Manual, Ver. 6.0 May 2021. Hydr- ologic Engineering Center, Davis, California, USA.

BRUNNER G.W., G. SAVANT AND R.E. HEATH. 2020. Modeler Application Guidance for Steady vs Unsteady, and 1D vs 2D vs 3D Hydraulic Modeling. Hydrologic Engineering Center, Davis, California, USA.

COOMBES P. AND S. ROSO. 2019. A guide to flood estimation, Book 9: Runoff in urban areas. The Australian Rainfall and Runoff, Barton, Australia.

DASALLAS L., Y. KIM AND H. AN. 2019. Case Study of HEC-RAS 1D-2D Coupling Simulation: 2002 Baeksan Flood Event in Korea. Water 11(10): 2048. https://doi.org/10.3390/w11102048

DE VRIES A.J., E. TYRLIS, D. EDRY, S.O. KRICHAK, B. STEIL AND J. LELIEVELD. 2013. Extreme precipitation events in the Middle East: Dynamics of the Active Red Sea Trough. Journal of Geophysical Research: Atmospheres 118:70877108. https://doi.org/10.1002/jgrd.50569

Dewan, A. 2013. Modeling flood hazards. in Floods in a megacity: Geospatial techniques in assessing hazards, risk and vulnerability. Springer, Dordrecht, Netherlands. https://doi.org/10.1007/978-94-0075875-9_5

DI BALDASSARRE, G. 2013. Floods in a Changing Climate: Inundation Modelling. Cambridge University Press, Cambridge, UK. https://doi.org/10.1017/CBO9781139088411.

DIEHL R.M., J.D. GOUREVITCH, S. DRAGO AND B.C. WEMPLE. 2021. Improving flood hazard datasets using a low-complexity, probabilistic floodplain mapping approach. PloS ONE. 16(3):e0248683. https://doi.org/10.1371/journal.pone.0248683

ELDHO T.I., P.E. ZOPE AND A.T. KULKARNI. 2018. Urban flood management in coastal regions using numerical simulation and geographic information system. In P. SAMUI, D. KIM AND C. GHOSH (Eds), Integrating Disaster Science and Management 205-219. Elsevier, Amst., Netherlands. https://doi.org/10.1016/B978-0-12-8120569.00012-9

EL BASTAWESY M., K. WHITE AND A. NASR. 2009. Integration of remote sensing and GIS for modelling flash floods in Wadi Hudain catchment, Egypt. Hydrological Processes 23(9): 1359-1368. https://doi.org/10.1002/hyp.7259

EL KENAWY A.M., M.F. MCCABE, J.I. LOPEZMORENO, Y. HATHAL, S.M. ROBAA, A.L. AL BUDEIRI, K.Z. JADOON, A. ABOUELMAGD, A. EDDENJAL, F. DOMÍNGUEZ-CASTRO, R.M. TRIGO AND S.M. VICENTE-SERRANO. 2019. Spatial assessment of the performance of multiple high-resolution satellite-based precipitation data sets over the Middle East. International Journal of Climatology39(5):2522-2543. https://doi.org/10.1002/joc.5968.

ELEWA H.H., A.M. NOSAIR AND E.M. RAMADAN. 2020. Sustainable Development of Mega Drainage Basins of the Eastern Desert of Egypt: Halaib-Shalatin as a Case Study Area. In A. Negm (Ed.), Flash Floods in Egypt 141-204. 
Springer, Cham, Switzerland. https://doi.org/10.1007/978-3-030-29635-3_9.

ELNAZER A.A., S.A. SALMAN AND A.S. ASMOAY. 2017. Flash flood hazard affected Ras Gharib city, Red Sea, Egypt: A proposed flash flood channel. Natural Hazards 89: 1389-1400. https://doi.org/10.1007/s11069-017-3030-0

EL-TAWEEL M.I. AND M.M. KOTB. 2006. Land Resources in Wadi Hodein Area, Southeastern Desert of Egypt. The 2nd International Conf. on Water Resources and Arid Environment, Riyadh, KSA.

EMA (Egyptian Meteorological Authority). 1996. Climatic Atlas of Egypt. Cairo, Egypt. EMA (Egyptian Meteorological Authority). 2011. Climatological Normals for the Arab Republic of Egypt, Surface Stations, for 1976 to 2005. Cairo, Egypt.

FATHY I., H.F. ABD-ELHAMID AND A.M. NEGM. 2020. Prediction and mitigation of flash floods in Egypt. In A. Negm (Ed.), Flash Floods in Egypt 349-368. Springer, Cham, Switzerland. https://doi.org/10.1007/978-3-030-29635-3_15

FOODY G.M., E.M. GHONEIM AND N.W. ARNELL. 2004. Predicting locations sensitive to flash flooding in an arid environment. Journal of Hydrology292:48-58. https://doi.org/10.1016/j.jhydrol.2003.12.045

GADO, T.A. 2020. Statistical Behavior of Rainfall in Egypt. In A. Negm (Ed.), Flash Floods in Egypt 1330.Springer, Cham, Switzerland.

https://doi.org/10.1007/978-3-030-29635-3_2

GENERAL ORGANIZATION FOR PHYSICAL PLANNING. 1995. Master plan of Shalatin city. Final report. Cairo, Egypt. (in Arabic)

GHANEM, M. 1972. Geology of Wadi Hodein Area. Annal of the Geological Survey of Egypt 2: 199214.

GHEITH H. AND M. SULTAN. 2002. Construction of a hydrologic model for estimating Wadi runoff and groundwater recharge in the Eastern Desert, Egypt. J. of Hydrology263:36-55.

https://doi.org/10.1016/S0022-1694(02)00027-6

GHONEIM E., N. ARNELL AND G. FOODY. 2002. Characterizing the Flash Flood Hazards Potential along the Red Sea Coast of Egypt. In Á. Snorasson, H.P. Finnsdóttir AND M.E. Moss (Eds.), The Extremes of the Extremes: Extraordinary Floods. International Association of Hydrological Sciences Publications, 271: 211-216.

HEMMATI M., B.R. ELLINGWOOD AND H. N. MAHMOUD. 2020. The role of urban growth in resilience of communities under flood risk, Earth's Future,8(3):e2019EF001382. https://doi.org/10.1029/2019EF001382

HERMAS E., A. GABER AND M. EL BASTAWESY. 2021. Application of remote sensing and GIS for assessing and proposing mitigation measures in flood-affected urban areas, Egypt. The Egyptian Journal of Remote Sensing and Space Sciences 24 119-130. https://doi.org/10.1016/j.ejrs.2020.03.002

LAMOND J.E., D.G. PROVERBS, C.A. BOOTH AND F.N. HAMMOND. 2012. Flooding in the built environment: Changing risk and an overview of impacts. In J.E.LAMOND, C.A. BOOTH, F.N. HAMMOND, D.G. PROVERBS. Flood hazards: Impacts and responses for the built environment. CRC Press, Boca Raton, Florida.

MASHALY J. AND E. GHONEIM. 2018. Flash flood hazard using optical, radar, and stereo-pair derived DEM: Eastern Desert, Egypt. Remote Sensing 10: 1204. https://doi.org/10.3390/rs10081204

MASOUD, A.A. 2004. Flash flood potential, mitigation, and floodwater resource management integrating remote sensing and GIS technologies in Safaga Area, Egypt. Journal of Geosciences, Osaka City University 47: 21-38.

MAZZOLENI, M. 2016. Improving Flood Prediction Assimilating Uncertain Crowdsourced Data into Hydrologic and Hydraulic Models. CRC Press, Boca Raton, Florida, USA. https://doi.org/10.1201/9781315115979

METEOROLOGICAL AUTHORITY. 1979. Climatological Normals for the Arab Republic of Egypt up to 1975. Cairo, Egypt.

METEOROLOGICAL DEPARTMENT. 1950. Climatological Normals for Egypt. Cairo, Egypt.

MILITARY SURVEY AUTHORITY. 2003. Shalatin, 1/25,000. (topographic map, in Arabic).

MORSY M., T. SAYAD AND A.S. KHAMEES. 2020. Towards instability index development for heavy rainfall events over Egypt and the Eastern Mediterranean. Meteorology and Atmospheric Physics 132: 255-272.

https://doi.org/10.1007/s00703-019-00686-5 MUJUMDAR P.P. AND D.N. KUMAR. 2013. Floods in a Changing Climate: Hydrologic Modeling. Ca-mbridge University Press, Cambridge, UK. https://doi.org/10.1017/CBO9781139088428

NARSS. 1997. Hazard Assessment and mitigative measures of flash flooding on the Red Sea towns, National Authority for Remote Sensing and Space Sciences, Cairo, Egypt. (Unpublished report). OMRAN A., D. SCHRÖDER, A. EL RAYES AND M. GERIESH. 2011. Flood hazard assessment in Wadi Dahab, Egypt based on basin morphometry using GIS techniques. In A. CAR, G. GRIESEBNER AND J. STROBL (Eds), Geospatial crossroads GI_Forum '11 Proceedings of the Geoinformatics Forum Salzburg, Wichmann Verlag, VDE Verlag, Berlin, Germany. DOI:10.13140/RG.2.1.2502.1520

PHYSICAL DEPARTMENT. 1938. Climatological Normals for Egypt and the Sudan, Cyprus and Palestine. Government Press. Bulaq, Egypt.

RAJKHOWA S. AND J. SARMA. 2021. Climate change and flood risk. In S. SINGH, P. SINGH, S. RANGABHASHIYAM and K.K. SRIVASTAVA global climate change Elsevier. Amsterdam, Netherlands. https://doi.org/10.1016/B978-0-12822928-6.00012-5

SADEK, M.F. 2009. Geological and Structural Setting of Wadi Hodein area, southeast Egypt with remote sensing applications. The International Archives of 
the Photogrammetry, Remote Sensing and Spatial Information Sciences XXXVII(Part B8): 12451249.

SHABANA A.R., O.S. AGLAN, B.M. MOUSSA AND F.A. HAMMAD. 2003. Hydrogeological studies on Rahba-Hodein basins, Southeast Egypt. Annals of the Geological Survey of Egypt 26: 421-447.

SMITH G.P., E.K. DAVEY, R.J. COX. 2014. Flood hazard, WRL technical report 2014/07 30. UNSW Australia Water Research Laboratory.

SOLOMATINE, D.P. AND T. WAGENER. 2011. Hydrological Modeling. In P. Wilderer (Ed.) Treatise on Water Science, Vol. II. Elsevier, Amsterdam,Netherlands. https://doi.org/10.1016/B978-0-444-531995.00044-0

WANG Y., A.S. CHEN, G. FU, S. DJORDJEVIĆ, C. ZHAN AND D.A. SAVIĆ. 2018. An integrated framework for high-resolution urban flood modelling considering multiple information sources and urban features. Environmental Modelling and Software107:85-95. https://doi.org/10.1016/j.envsoft.2018.06.010
WHEATER, H.S. 2008. Modelling hydrological processes in arid and semi-arid areas: An introduction. In H.S. WHEATER, S. SOROOSHIAN AND K.D. SHARMA. Hydrological modeling in arid and semi-arid areas, Cambridge University Press, Cambridge,UK. https://doi.org/10.1017/CBO9780511535734.002

WMO AND GWP (WORLD METEOROLOGICAL ORGANIZATION AND GLOBAL WATER PARTNERSHIP). 2013. Flood mapping. Integrated Flood Management Tools Series No.20. World Meteorological Organization, Geneva, Switzerland.

YEHIA M.A., M.H. ASHMAWY AND H.A. EL-ETR. 2000a. flash flooding threat to the Red Sea coastal towns of Ras Gharib and Hurghada. The Egyptian J. of Remote Sensing and Space Science 2: 87-106.

YEHIA M.A., M.H. ASHMAWY, H.A. EL-ETR, H. ABDEL MONSEF, I.Z. EI SHAMY, E.A. HERMAS, M.N. HIGAZY AND S.M. HASSAN. 2000b. flash flooding threat to the Red Sea coastal towns of Safaga, Quseir and Marsa El Alam. The Egyptian Journal of Remote Sensing and Space Science 2: 69-86.
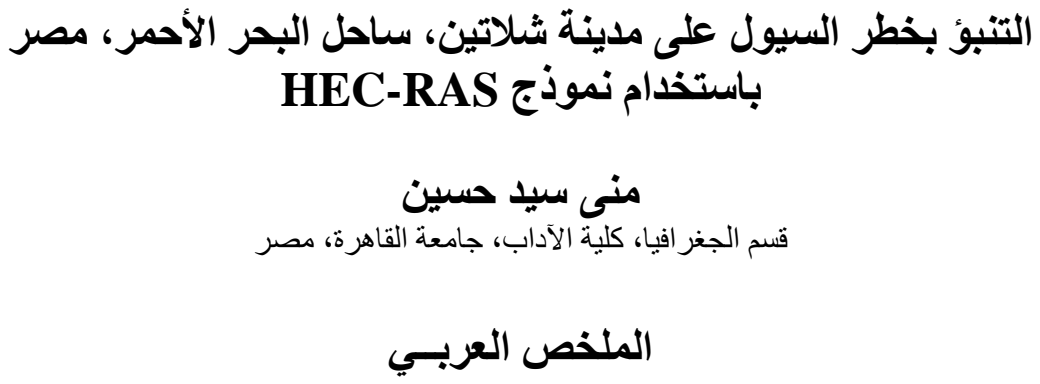

تعد شلاتين أقل المدن الساحلية الست الرئيسة في محافظة البحر الأحمر المصرية من حيث نصيبها من در اسة خطر السيول.

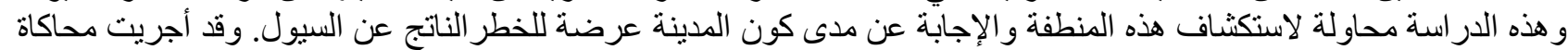

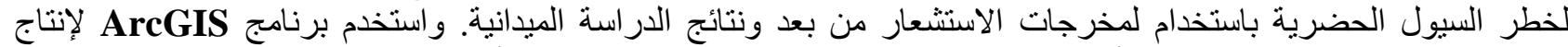

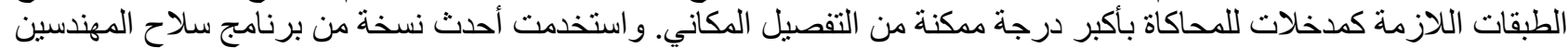

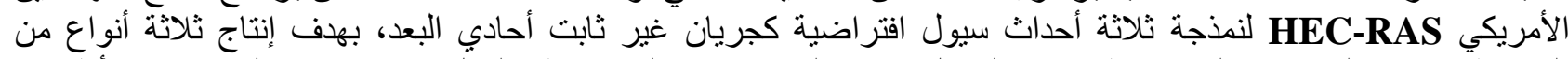

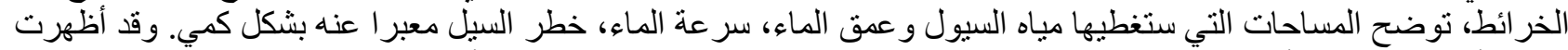

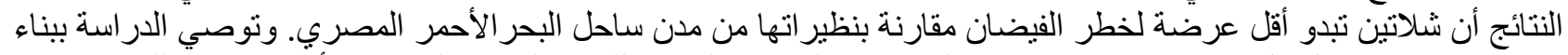

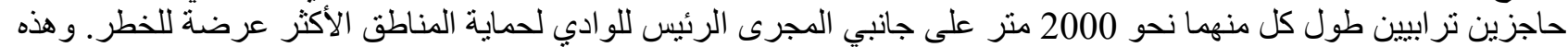

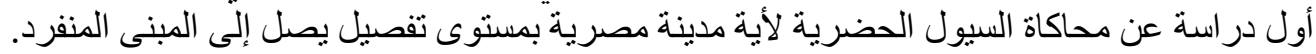

